\title{
Teacher Opinions on the Problems Faced in Reading and Writing by Syrian Migrant Children in Their First Class at Primary School
}

\author{
Necla Işıkdoğan Uğurlu ${ }^{1} \&$ Nilay Kayhan ${ }^{2}$ \\ ${ }^{1}$ Faculty of Education, Department of Special Education, International Cyprus University, Lefkoşa, Cyprus \\ ${ }^{2}$ Faculty of Education, Department of Special Education, Hasan Kalyoncu University, Gaziantep, Turkey \\ Correspondence: Necla Işıkdoğan Uğurlu, Faculty of Education, Department of Special Education, International \\ Cyprus University, Lefkoşa, Cyprus. E-mail: nugurlu@ciu.edu.tr or nilaykayhan@gmail.com
}

Received: October 22, 2017

Accepted: November 19, 2017 Online Published: December 21, 2017

doi:10.5539/jel.v7n2p76

URL: http://doi.org/10.5539/jel.v7n2p76

\begin{abstract}
The objective of this study is to evaluate, according to the opinions of teachers, the problems faced by the children of Syrian families who have taken refuge in Turkey since 2011 with regard to their linguistic and communication skills, as well as their reading and writing process in Turkish as a foreign language. The research group is composed of seven teachers working in the first class of public primary schools attended by Syrian children. The study, which is based on the statements and perceptions of teachers, has been designed with the descriptive approach in the qualitative research method. Linguistic problems faced by Syrian immigrant children during their reading and writing process in Turkish as a foreign language, as well as the opinions of teachers on solution recommendations, are treated in detail in the study. The opinions of teachers are assessed under four main theme: Opinions on preparatory processes of instructing Turkish as a foreign language; opinions on communication approaches and the program implemented during the instruction of reading and writing; the importance of cooperation in the solving of problems; and opinions on instructing Turkish to Syrian children in a more effective manner. The study found that class teachers experience many problems in teaching Turkish reading and writing as a foreign language to Syrian students, as well as developing their linguistic and communication skills. The findings also reveal that teachers tend to look for support from their colleagues and other students in their classes, rather than from the families of children.
\end{abstract}

Keywords: immigrant children, foreign language, reading-writing

\section{Introduction}

Individuals use their language skills to share their feelings, thoughts and wishes, and to exchange information. Language is an instrument used for realizing certain functions such as expressing feelings, thoughts, attitudes and beliefs, learning, transferring cultural characteristics and accumulation, as well as for asking questions and making wishes. Individuals make sense of their environment according to the characteristics of the language in which they are born. Language is therefore one of the basic instruments for understanding a society, and it also has an important place in the acquisition of historical information and in the transfer of experience and culture (Kırkkılıç, 2002).

As a communication tool, linguistic skills separate societies from each other as much as they regulate their relations (Yalçın-Şengül, 2007). Individuals learn the linguistic skills of other societies through language and they may also transfer the cultural characteristics of that society to their own culture. In sum, the fact that individuals learn a second language in addition to their native language also means that they learn the cultural and historical codes of the language they are learning (İşcan, 2011).

These days, the development of science and technology affects the quality of services provided by countries to their citizens. Those services, namely education-training and health services, are accepted as one of countries' key development indicators. Because of this, qualified education programs are required during pre-school and primary school, which are educational periods that shape the future. These regulations are important in terms of cognitive, social and linguistic development, children's communication, and their acquisition of basic information and skills.

The arrangements should be planned in order to meet the requirements of each individual, without making any 
discrimination on the basis of language, religion, race and gender. Especially in recent years, when the concepts of multiculturalism, migration and global citizenship have become prominent, Turkey has started to bring in more migrants. But immigration is not a new phenomenon. For as long as humanity has existed, humans have moved between regions voluntarily or involuntarily. Mostly, migration has been due to people moving away from an environment of disturbance (Akkaya, 2013). Individuals may migrate within his/her homeland or to a different country. This situation brings together many social changes, such as the adaptation of the family to the new environment, their social relations, their language and communication skills, their cultural characteristics, etc.

The civil war that started in Syria in 2011 has negatively affected life for all living in the country. Turkey, which has a long border with Syria, has not remained indifferent to the war happening in the country and has followed a strategy of providing support to displaced Syrians. The Republic of Turkey implemented an open-door policy to its neighbors during this challenging process and 2.5 million Syrian citizens entered in Turkey. Turkey was estimating immigration issue was temporary and had planned temporary for supplying shelters and food supplies. In this manner, Turkey did not consult any long-time solution for the immigration. Studies and reports have been shown that population of Syrian immigrants rapidly increasing because of civil war and violence is still proceeding since 2011, therefore requirment of permanent solutions have been pointed (AFAD, 2014; Jennifer, 2015; Kilberg, 2014; UNHCR, 2015; UNICEF, 2015; ECHO, 2015). According to European Commission Humanitarian Aid and Civil Protection (ECHO) (2015) from May 20153.6 million of 7.6 million immigrants entered to Turkey, Lebanon and Jordan. It is indicated that $54 \%$ (more than 1 million) of the migrants coming to Turkey from Syria are children who have left their education uncompleted (Emin, 2016). Many migrants have been settled in tent cities established for them and certain legal regulations have been made to let them benefit from essential services related to education, health and work. In order to benefit from these services at the maximum level, Syrian citizens need to learn Turkish and communication skills. Different works are being carried out in this area for teaching Turkish and Turkish instruction centers are being opened. The services are being planned by the Ministry of National Education, universities and non-governmental organizations.

United Nations Educational, Scientific and Cultural Organization (UNESCO) (2011) mentioned Syrian children have less benefits rather than other children and they do not completely benefit their education rights, therefore several troubles could be occur such as, exploitation, harm, after trauma stress disorder, physical and psychological development disorder. Because more than half of the Syrians at school age are pre-school and primary school children, the "Circular Numbered 2014/21 on the Education-Training Services Aimed at Foreigners" concerning Syrian children who are at school age entered into force. According to this Circular, Syrian children should receive education in temporary education centers established inside and outside camps. For those outside camps, Syrian children should receive education in public schools and newly opened private schools (Ministry of National Education, 2014).

Syrian students who become integrated into the education system in Turkey face problems in many areas including instruction programs, personnel, lack of equipment, physical conditions and infrastructure. Their inability to speak Turkish effectively, leading to inadequate communication skills, is also among the major problems. In addition, the fact that education is only made in temporary education centers and that there is no structured curriculum in public schools are also significant problems. The fact that teachers do not have enough vocational education on the type of the instruction method they should use in the instruction of Turkish to Syrian children is another fundamental problem. These problems remain unsolved in the advanced phases, as teachers and directors cannot allocate enough time to them.

The educational problems of Syrian children remained in the background until 2013. After then, works in this area started to be intensified. For Syrians who have migrated to Turkey, speaking Turkish is considered to be an important tool for them to reach different goals such as continuing their lives more comfortably, finding a job, continuing their education, and benefiting from health services (Seydi, 2014). Determining the language learning requirements of Syrian individuals who come together with different objectives in order to adapt to life in Turkey, determining individuals who intend to learn Turkish, preparing instruction by considering these requirements and carrying it out in accordance with programs, are important for Syrians' adaptation to life in Turkey.

Like many other foreigners, Syrians who try to learn Turkish face a number difficulties. These difficulties derive from the fact that their native language and Turkish have a different grammatical structure. The Turkish language is one of the agglutinating languages and paragoges are added sequentially. Various studies have suggested that such characteristics have an adverse impact on the learning of Turkish by foreigners (Ayaz \& Akkaya, 2010; Akış, 2010; Yıldırım, 2011). The native language of Syrians is Arabic. Arabic is different from 
Turkish with regard to its letters as well as its writing. While Turkish is written from the left to the right, in Arabic it is the opposite. This situation also negatively affects the instruction of Turkish. It is known that Syrians who are able to learn Turkish can express themselves better in society and communicate with Turkish people.

In Turkey, Turkish is taught as the native language in public schools such as primary schools and high schools. However, Turkish is taught to Syrian children as a foreign language. The native language of individuals and their cultural structure play an important role in the development of their personality. Besides genetic characteristics, the language of society, its culture, its way of life, decisions, thoughts and successes ensure the development of the native language (Tosun, 2006). As a result, Syrians residing in Turkey also continue their education related to the Arabic language. In Turkey, Syrian children are taught how to read and write in Turkish in general education schools. Under these circumstances, classroom teachers have the biggest responsibility regarding the instruction of writing and reading in Turkish. However, classroom teachers face different problems in the instruction of Turkish to foreigners and they do not know how to instruct a second language. Thus, considering the experiences of classroom teachers, it is necessary to examine the problems encountered by teachers in the instruction of reading and writing Turkish to Syrian children as a second language, and to express their opinions on the possible solutions to those problems. On the other hand, initial reading and writing instruction forms the basis of expression and in the effective understanding of the language. In this framework, the reading and writing skills of Syrian children, as well as their skills in understanding what they write, should be developed at an early age.

As Syrian children of school age also acquire such skills in Turkey's general education schools-just like every child - it is considered that the opinions and suggestions of classroom teachers would contribute to the literature, to the related regulations, and to the quality of the education and training arrangements of Syrian children.

\section{Objective of the Study}

The objective of this study is to evaluate, according to the opinions of teachers, the problems faced by children of Syrian families who have taken refuge in Turkey since 2011, in their first class at primary school, with regard to their linguistic and communication skills and their reading-writing process in Turkish as a foreign language.

\section{Method}

\subsection{Research Model}

The study is designed with a descriptive approach based on the qualitative research method (Creswell, 2005; Yıldırım \& Şimşek, 2011). The research group is composed of teachers working in the first class of public primary schools attended by Syrian children in the city center of Gaziantep. Linguistic problems faced by Syrian migrant children during their reading and writing process in Turkish as a foreign language, as well as the opinions of teachers on solution recommendations, are addressed in detail in the study.

\subsection{Working Group}

Purposive sampling has been preferred in the study. Purposive sampling methods take place within the qualitative research tradition. According to Patton (1987), this method enables researchers to deeply analyze and understand situations that are thought to have rich information content. In this respect, the purposive sampling method is used in studies aimed at exploring and explaining facts and events (Yıldırım \& Şimşek, 2011). Four criteria were used in determining the participant teachers: They must be working in a general education school with Syrian migrant children attending classes; they must have completed their undergraduate studies classroom teaching and have been nominated as a classroom teacher; they must be teaching first class primary school students in the school where the participant works; and they must voluntary give support to the study. The city center, where Syrian migrants are mostly located and where the second writer works, was considered for accessing classroom teachers who meet the necessary criteria.

The second writer first determined the places where Syrian migrants tend to live in the center of Gaziantep, as well as the schools attended by their children, and then contacted the administrators of those schools. In the face-to-face conversations with the school administrators, the second writer explained the objective of the study and shared information on its implementation. The administrator linked to the Ministry of National Education in the Şahinbey district, as well as the primary school first class teachers working in the public general education primary school, were included in the study as they declared that they would voluntarily participate in the study. The working group is composed of seven classroom teachers - three men and four women - working in the primary school attended by Syrian children in Gaziantep's Şahinbey district during the spring term of the school year 2016-17. The codes Ö1, Ö2, Ö3, Ö4, Ö5, Ö6, Ö7 are used in order to not disclose the personal information of teachers, based on the principle of confidentiality. In qualitative research, the characteristics of participants 
are given in detail. Therefore, the demographic characteristics of classroom teachers participating in the study are given in Table-1 (Creswell, 2005).

Table 1. Demographic characteristics of the participants

\begin{tabular}{|c|c|c|c|}
\hline \multicolumn{2}{|l|}{ Characteristics of the Participants } & \multirow{2}{*}{$\begin{array}{l}\mathbf{N} \\
4\end{array}$} & \multirow{2}{*}{$\begin{array}{ll}\% \\
57.1\end{array}$} \\
\hline Gender & Female & & \\
\hline & Male & 3 & 42.9 \\
\hline \multirow[t]{3}{*}{ Age } & Between 20-25 & 1 & 13.4 \\
\hline & Between 26-30 & 3 & 42.9 \\
\hline & Between 31-35 & 3 & 42.9 \\
\hline Educational Status & Undergraduate & 7 & 100 \\
\hline \multirow[t]{2}{*}{ Marital Status } & Married & 4 & 57.1 \\
\hline & Single & 3 & 42.9 \\
\hline \multirow[t]{2}{*}{ Professional Experience (Years) } & $1-5$ years & 2 & 28.6 \\
\hline & $6-10$ years & 5 & 71.4 \\
\hline Socio-Economic Level of the School Where the Study Was Conducted & Low & & 100 \\
\hline \multirow[t]{2}{*}{ Taking communication, language development courses } & Yes (Ö3, Ö4, Ö7) & 3 & 42.9 \\
\hline & No & 4 & 57.1 \\
\hline \multirow[t]{2}{*}{ Did the teacher participate in in-service training on language? } & Yes (Ö4) & 1 & 14.3 \\
\hline & No & 6 & 85.7 \\
\hline \multirow{2}{*}{$\begin{array}{l}\text { Receiving courses, lessons at university with regard to the education of } \\
\text { bilingual children }\end{array}$} & Yes (Ö4) & 1 & 14.3 \\
\hline & No & 6 & 85.7 \\
\hline \multirow[t]{3}{*}{ Age range of students in the class } & $5-7$ years & 3 & 42.9 \\
\hline & $6-8$ years & 2 & 28.6 \\
\hline & $7-10$ years & 2 & 28.6 \\
\hline \multirow[t]{2}{*}{ Classroom size } & $31-35$ students & 5 & 71.4 \\
\hline & $36-40$ students & 2 & 28.6 \\
\hline Are there any inclusive students in the class? & Yes (Ö1, Ö2, Ö3, Ö4, Ö5, Ö6, Ö7) & 7 & 100 \\
\hline Teachers who have students recognized to be speaking the language & Yes (Ö6) & 1 & 14.3 \\
\hline \multirow[t]{3}{*}{ Communication preferences with the Syrian student } & $\begin{array}{l}\text { Support of peer students who speak the } \\
\text { language }(\ddot{O} 1, \text { Ö4, Ö5) }\end{array}$ & 3 & 42.9 \\
\hline & Use of gestures, mimics & 3 & 42.9 \\
\hline & Not being able to communicate at all & 1 & 14.3 \\
\hline From who does the teacher receive the most efficient support? & From experienced colleagues & 7 & 100 \\
\hline Resources considered during the instruction process & $\begin{array}{l}\text { Publications of language speaking } \\
\text { specialists, videos containing their } \\
\text { opinions, scientific articles }\end{array}$ & 7 & 100 \\
\hline
\end{tabular}

As seen in Table 1, all participant teachers graduated from university. Four are women (57.1\%) and three are men (42.9\%). Most of the participants are aged between 26 and 30 (85.9\%) Four of the participants are married $(57.1 \%)$ and most (71.4\%) have professional experience of between six and 10 years. All teachers pointed out that the socio-economic level of the school where they work is low. Ö3, Ö4 and Ö7, meanwhile, indicated that they had taken courses on communication and linguistic development. Only one participant (Ö4) participated in in-service training on language and communication and it was also observed that most participants (85.7\%) did not receive any lessons on the education of bilingual children during their education and training.

The students in the study generally aged between 5 and 8 years old (5-7 years old 42.9\%, 6-8 years old $28.6 \%$ ). Most of them (71.4\%) were in classrooms that held between 31 and 35 children. All teachers indicated that along with Syrian children, students with different requirements in different fields were present in their class. They also stated that they received support from students who were able to speak the language Syrian students and could therefore communicate with them more effectively (Ö1, Ö4, Ö5). Teachers said they gave particular importance to the use of gestures and mimics (Ö2, Ö3, Ö7). Only one of the teachers said he had a lot of difficulty and he could not communicate at all (Ö6). All teachers indicated that they received the most useful support from colleagues who had experience instructing reading and writing to children learning Turkish as a second language. Teachers also said that during their instruction process, they preferred resources that included the opinions of specialists in the area of language speaking. 


\subsection{Data Collection Tool}

A questionnaire form was prepared to determine the problems faced by teachers, their solution suggestions, and their requirements during the teaching of Turkish as a foreign language to Syrian children attending the first class of primary school. The data obtained through this form was evaluated with the content analysis. The questionnaire form prepared to collect data consists of two sections. The first section contains information on the age, gender, educational status, civil status, and professional seniority of teachers; their perception of the socio-economic status of the school where they work; whether they have received courses on language development and speaking; whether they have participated in in-service training on language and communication in terms of education and training of children learning Turkish as a second language; the age range of students in the classroom under their responsibility; the communication methods they prefer in the classroom; their opinions on the preference of verbal and nonverbal communication; whether or not, apart from Syrian students, they have successful students or students having difficulties in class; and the resources they use in their professional practices while working with Syrian children.

Some of the 10 questions included in the written interview form are presented in Appendix A.

\subsection{Environment and Data Collection}

The data collection in the study was carried out in two stages. The second writer visited the determined primary school and gave preliminary information to the teachers of first classes at the school. Data was collected in the school's Teacher's Lounge. As the teachers worked in the afternoon, the interviews were carried out during the hours when participant teachers were not in class but other teachers were in class. Considering the physical characteristics of the school (voice, light and temperature etc.), this environment was preferred as the most appropriate environment in the circumstances.

Interview and observation are the two techniques frequently used for data collection in qualitative research. Taking into consideration this matter, with a view to collecting the research data, the researcher distributed to teachers the demographic data forms and written interview forms containing open-ended questions, prepared after taking the opinions of specialists. The researcher also conducted some individual interviews with teachers as they were filling out the forms, visited them in their classrooms, and observed the Turkish classes.

Although face-to-face interviews were conducted, audio recordings could not be made during the study because the physical environment was not appropriate and because four of the seven teachers preferred to give a written record instead of an audio record. The second researcher took the written statements of the participants, in which they responded to each question. The second researcher also took written notes before, during and after the interviews, made observations on classes, and obtained supportive data.

This enabled researchers to obtain deeper meaning from the data obtained through qualitative research. Hence, qualitative literature research indicating that participants play an important role is supported through both numbers and observation notes, voices and documents (Bogdan \& Biklen, 2007; Yıldırım \& Şimşek, 2011).

\subsection{Analysis of Data}

Data collected through the written interview form was analyzed with the content analysis method. With a view to evaluating the data from an integrated approach, the writers considered the observation notes taken by the second writer during classes, as well as the written records of interviews made by the second writer with teachers. The perceptions, experiences and statements of classroom teachers were considered in determining the difficulties they faced and the solution suggestions they made with regards to the reading comprehension and writing work they did with immigrant Syrian children attending the first class at primary school.

With regard to the content analysis, there are two types of approach: The deductive approach and the inductive approach (Elo \& Kyngas, 2008). In this study, in which the inductive approach was adopted, categories were formed as a result of data analysis, and themes and sub-themes were reached from those categories.

The opinions of participants were considered objectively in order to ensure reliability and validity during the transformation of research data into findings. Both writers of the study have a bachelor's degree in classroom teaching and have been working as classroom teachers in public schools, especially in inclusion classes. The writers hold doctoral degrees in the field of special education and they are working as academic members in the departments of special education in the education faculties of two different foundation universities. They give graduate and undergraduate courses in the department of special education on linguistic and cultural differences; and on the supporting of academic, social, linguistic and communication skills of children who are mentally disabled, visually impaired and hearing impaired. The first writer conducts applied research on the education of individuals with special requirements, and the supporting of hearing impaired individuals during their reading 
and writing processes. The second writer conducts applied research on instructional arrangements in the educational environment of individuals with different requirements, individuals showing developmental differences compared to their peers, the educational and professional requirements of working teachers, the supporting of classroom teachers with regard to their practical skills in the area of special education, services aimed at disabled higher education students, and games and drama in special education.

With regard to the validity of the research, the researchers cooperated with two different specialists working in the field of special education on linguistic development, communication and instruction of Turkish as a foreign language. The researchers abided by the principle of seeking the approval of colleagues through data triangulation (Yıldırım \& Şimşek, 2011).

They calculated the reliability level through considerations of replicability and reliability between coders. The fact that the concordance ratio is high between coders in qualitative research shows that the reliability of data measurements is high. The sub-themes and themes derived from the opinions of classroom teachers, as well as the forming of the findings, were submitted for the examination of two specialists. The specialists have practical experience with and have conducted research on special education, linguistic development, communication, methods and techniques used in linguistic support for children with Turkish as a second language, primary school Turkish course instruction scheduling, reading and writing activities for children with special requirements, first reading and writing instruction, adjacent italic writing, and the audio-based sentence method. A reliability analysis was carried out between sub-themes and coders (Creswell, 2005; Yıldırım \& Şimşek, 2011).

The reliability ratio between coders was calculated at $94 \%$ in the study by using the formula Reliability $=$ [Consensus / (Consensus+Dissensus)] x 100 (Miles and Huberman, 1994). According to this result, the study has been accepted as reliable.

\section{Findings}

The opinions of teachers participating in the study were gathered under four main themes: "Opinions on preparatory processes for instructing Turkish as a foreign language; opinions on communication approaches and the implemented program during the instruction of reading and writing; the importance of cooperation in the solving of problems; and opinions on instructing the Turkish language to Syrian children in a more effective manner." The answers of classroom teachers were established in the form of direct citations under the themes. The quantitative values presented in Table 2 show the percentages and frequency ranges of answers, reflecting the opinions and thoughts of a participant in more than one sub-theme and in different main themes. As a result, the opinions of seven teachers are gathered under 74 frequency ranges. The percentage value of each sub-theme shows that participants have frequently expressed opinions on this theme.

Table 2. Main and sub-themes derived from the opinions of teachers

\begin{tabular}{|c|c|c|}
\hline & $\mathrm{F}$ & $\%$ \\
\hline \multicolumn{3}{|l|}{ 1. Opinions on the preparatory processes of instructing Turkish as a foreign language } \\
\hline 1.1. Readiness of Syrian students for the instruction of Turkish & 7 & 100 \\
\hline 1.2. Opinions of teachers on their professional competency with regard to the instruction of Turkish as a foreign language & 5 & 71.4 \\
\hline \multicolumn{3}{|l|}{$\begin{array}{l}\text { 2. Opinions on communication approaches and the program implemented during the instruction of reading and } \\
\text { writing }\end{array}$} \\
\hline 2.1. Opinions on communication approaches preferred in the education of Syrian students and their effectiveness & 7 & 100 \\
\hline 2.2. Efficient arrangements (material, instruction instrument, etc.) preferred during the in-class instruction process & 7 & 100 \\
\hline \multicolumn{3}{|l|}{ 3. Opinions on the importance of cooperation for solving the problems } \\
\hline 3.1. Cooperating with personnel experienced in working with children who know Turkish as a foreign language & 7 & 100 \\
\hline 3.2. Opinions on the impact of support from peers who speak Turkish as their native language & 7 & 100 \\
\hline 3.3. Opinions on family participation and its impact on the program & 6 & 85.7 \\
\hline \multicolumn{3}{|l|}{ 4. Opinions on teaching Turkish to Syrian children in a more effective manner } \\
\hline 4.1. Preparation of Turkish instruction materials for children & 7 & 100 \\
\hline 4.2. Taking teachers to education related to Turkish & 7 & 100 \\
\hline 4.3. Establishment of education modules related to the instruction of Turkish & 7 & 100 \\
\hline \multirow[t]{2}{*}{ 4.4. Preparation of inclusion environments with regard to harmony and academic skills } & 7 & 100 \\
\hline & 74 & \\
\hline
\end{tabular}

As seen in Table 2, the opinions of teachers were been designed in four main themes: "Opinions on preparatory processes for instructing Turkish as a foreign language; communication approaches and the implemented 
program during the instruction of reading and writing; and the importance of cooperation in the solving of problems and opinions on instructing Turkish to Syrian children in a more effective manner"

\subsection{Opinions on the Preparatory Processes of Instructing Turkish as a Foreign Language}

The first theme, titled "Opinions on the preparatory processes of instructing Turkish as a foreign language," consists of two sub-themes titled "Readiness of Syrian students for the instruction of Turkish" and "Opinions of teachers on their professional competency with respect to the instruction of Turkish as a foreign language." In the context of this theme, teachers generally pointed out that there were no arrangements in the instruction program with regard to the use of Turkish as an instruction language during the reading and writing process of Syrian children. Seven teachers indicated that migrant Syrian families were not supporting the linguistic abilities of their children in Turkish in their social lives and within the family environment, and therefore the readiness of children for school was not similar to the readiness of their peers, apart from in terms of their physical development.

Some of the opinions are as follows;

$\ddot{\mathbf{O}} 3$ "The most important difficulty is that the linguistic development of children is not supported by their families at home."

Ö6 "Linguistic problems and cultural differences differentiate the school preparation process of children from the preparation process of their peers. Sometimes they do not even know the reason why they are coming to school."

Another issue pointed out by teachers is the fact that they did not find themselves professionally competent enough to work with children who speak a different language. The fact that they mentioned the lack of appropriate arrangements in the existing primary school programs for instructing Turkish as a foreign language is also remarkable. Teachers expressed their opinions as follows:

$\ddot{O} 1$ "In my opinion, the fact that necessary resources are missing and that there is no specialist assistance are the most importance deficiencies. At this point, newly appointed and inexperienced teachers are working together. Professional competence should be considered in addition to professional seniority."

$\ddot{0} 4$ "Children whose second language is Turkish do not have a command of Turkish. Children who are placed in crowded classes escape attention, so they end up having to learn the language and the program by themselves."

$\ddot{0} 7$ "The learning outcome objectives are not realistic for such students and do not address the needs."

With regard to the instruction of Turkish to Syrian students as a foreign language, some of the suggestions made by teachers are eye-catching, such as considering professional competencies in addition to professional seniority, receiving in-service training, and preparing adapted instruction materials.

4.2 Opinions on Communication Approaches and the Program Implemented during the Instruction of Reading and Writing

The second theme of the findings is titled "Opinionson communication approaches and the program implemented during the instruction of reading and writing." It consists of two different sub-themes and 14 frequency intervals. The first sub-theme is titled "Opinions on communication approaches preferred in the education of Syrian students and their effectiveness." The second sub-theme is titled "Effective arrangements (material, instruction tools, etc.) preferred in the in-class instruction process." Teachers stated that they generally preferred verbal communication and nonverbal communication in their classes. They also shared common opinions on the effectiveness of the use of gestures, mimics, visual materials, and the use of games as instruction tools.

For example:

$\ddot{O} 2$ "I explain reading comprehension texts by using nonverbal education, because they have problems in understanding."

$\ddot{O} 5$ "Generally I get help from people who speak that language, from the children. That is what we can do with our means. By doing so, I think I'm supporting peer interaction as well as their participation in the class. However, generally we cannot do much as teachers to ensure students' more efficient participation."

Teachers therefore point outed that the reading and writing abilities of Syrian children do not get developed at the class level as they have problems in understanding Turkish. On the other hand, as we examine the instruction methods used by teachers, their preferences with regard to the monitoring of the program and the evaluation of 
their students, we determine that they mostly prefer the observation method and that they consider visual materials to be highly efficient in establishing communication. For example,

$\ddot{O} 7$ "If the student can talk Turkish even a little, I use techniques that are not different than those I use for other students."

Ö3, Ӧ4, Ö6 "Visual materials. We try to establish partial communication only in that way."

Ö3, Ö6 and 07 "I prefer observation."

Ö5 "I try to make them act together as much as possible. I give them the right to speak."

The fact that teachers generally think they are working with students with different requirements (such as hearing and seeing) when they are instructing Turkish as a foreign language shows that they require instructional arrangements within the special education area, such as modules prepared for students diagnosed with speech disorders or learning disabilities. These topics, which were particularly emphasized by teachers during face to face interviews, were noted and it was determined that the following thoughts came to the fore.

Ö1 "First of all, I approach them without noticing that they are migrants, without distinguishing between them and other children. I support verbal interaction with nonverbal interaction. I benefit most from people specialized in language speaking."

Ö5 "I contact with people who speaking the language. I communicate by using visual materials, gestures and mimics. As for linguistic development, there are students who speak different languages. I have students who speak Arabic and Kurdish in my class. Speaking is a pre-condition for them to start writing and reading. Family and peer support seems to be highly effective. Sometimes language is reflected in thoughts. I feel that I have an advantage in understanding their language as I have worked in the area for a while. But the method I use to teach Turkish is to make them feel I understand nonverbal communication. Thus I am able to be successful by first mentioning that I understand them."

With regard to effective in-class instructional arrangements, teachers referred to a lack of resources in the materials they preferred and in the arrangements they made. Teachers also emphasized deficiencies concerning the physical environment, the instructional program, and legal regulations in this respect. It is important that although particularly young teachers who have newly started in the profession considered themselves to be competent, they pointed out infrastructure deficiencies concerning the use of information communication technologies in schools. Teachers mentioned technological deficiencies as being the lack of computers or projectors in each classroom and the lack of an internet connection at school.

Teachers who also emphasized the lack of materials criticized the fact that there were no written or oral resources for the instruction of Turkish as a foreign language in the first reading writing instruction program.

$\ddot{O} 1$ "We have so many problems with our resources. In truth they are insufficient. There are no resources that recognize individual differences. For this reason, I prefer practical methods of doing and applying. We use social media and internet resources but I only show them on the telephone. Because there is no internet at school. As the possibilities are limited at school, our most efficient materials are books. However the reading and writing activities of our curriculum are quite insufficient."

$\ddot{O} 3$ "I mostly prefer visual materials, videos and cartoons in the instruction of Turkish. The ministry should prepare more video materials. Our curriculum is so weak with respect to ICT (Information Communication Technologies). Films and game videos. I think the curriculum is insufficient.

\subsection{Opinions on the Importance of Cooperation for Solving the Problems}

The third main theme, titled "Opinions on the importance of cooperation," consists of three sub-themes and 20 frequency intervals. The first sub-theme is titled "Cooperation with experienced staff working with children whose foreign language is Turkish." The second sub-theme is titled "Opinions on the impact of peer support taken from children whose native language is Turkish." The last sub-theme is titled "Opinions on family participation and its impact on the program."

In terms of the first sub-theme regarding cooperation with staff experienced in working with children for whom Turkish is a foreign language, it is notable that teachers attached particular importance to experience as well as professional seniority with respect to special education and language matters concerning students with individual differences. The fact that the teachers' first place of duty are regions where different languages and cultures coexist was considered by teachers to be a positive contribution to the reading and writing instruction practices aimed at Syrian children. However, they said this contribution was only a social acknowledgment, and they required in-service training and support with regard to instructional arrangements. For example: 
Ö2 “... I particularly ask colleagues who have experience in language speaking. I want some support. I follow people who are specialized in language speaking."

Ö2, Ö3 particularly criticized the lack of classes in undergraduate education in this respect. They said they requested help from their colleagues instruct reading and writing to students with a different native language.

All teachers stated that they get the most important support from colleagues who are experienced in instructing reading and writing to children for whom Turkish is a foreign language. Similarly, they pointed out that they benefited from peer support with regard to Syrian children in their classrooms. They also stated that the early age of first class students was an advantage with respect to instruction through games, social acknowledgement and adaptation.

Ö1 "As the children are only in the first class of primary school, they cannot yet distinguish the effects of their differences on one another. I can say they have a very good relationship with migrant children. Therefore, I use peer interaction more frequently. They take as a model."

Ö5 "They cannot become mixed and socialized very quickly due to their differences. I prefer to make use of shared games and activities. Of course the process continues a little slowly, because they don't know the language."

\subsection{Opinions on Teaching Turkish to Syrian Children in a More Effective Manner}

As for their opinions on family participation and its impact on the program; teachers believe that students' families do not provide enough support, unlike colleagues and peers.

Ö1 "We cannot get feedback from families. I can get in touch with them on the telephone and face to face but our means are very restricted. There are families who cannot even speak our language."

Ö2 "I have two Syrian students. The mother of one of them cannot speak Turkish at all. I have to communicate through interpreters. They don't have a negative attitude but they also don't provide any support."

ö6 "As we also have some communication problems with the family, we cannot establish a healthy communication."

The main theme, titled “Opinions on instructing Turkish to Syrian children in a more effective manner," is composed of four different sub-themes and generally reveals suggestions about problems faced by teachers. Teachers who draw particular attention to the preparation of in-class arrangements and instructional materials stated that the individualization of instruction was one of the fields where they experience the most important difficulty.

Ö3 “As they came late, I prepared a special reading writing program for them. I implement a more individualized education. Sometimes we experience major difficulties. I need different and more effective model practices and education."

$\ddot{0} 5$ “We experience disciplinary problems from time to time. We also have some adaptation problems. I face even more problems as the students' number increases. I generally have to limit communication among them due to classroom management."

Thus, teachers argued that the problems they were facing stemmed from the lack of arrangements in the instruction program with regard to linguistic and cultural differences and from the requirements of professional information on the individualization of time and instruction.

As we generally examined the requirements of teachers to instruct Turkish in a more effective manner, we determined that they were related to the restricted means of professional development and to arrangements concerning students' participation in education.

When factors such as the lack of instruction materials and the socio-economic level of the school environment are also taken into consideration, teachers mentioned that they were in a disadvantageous position.

\section{For example:}

Ö1 "Our in-service training is insufficient. It is possible to make an arrangement, especially in order to provide help with respect to resources and materials."

$\ddot{O} 2$ "I think teachers should receive courses on behavior as well as instruction on this topic."

$\ddot{0} 4$ "Various measures might be taken according to the situation of the Syrian student. Some of the students do not speak Turkish at all. These students may benefit from an orientation related to Turkish." 


\section{Discussion and Conclusion}

The study is composed of four main themes based on the opinions of classroom teachers: "Opinions on the preparatory processes of instructing Turkish as a foreign language; opinions on communication approaches and the program implemented during the instruction of reading and writing; the importance of cooperation in the solving of problems; and opinions on instructing Turkish to Syrian children in a more effective manner." As we examined the sub-themes titled "The readiness of Syrian students for the instruction of Turkish" and "Opinions of teachers on their professional ability regarding the instruction of Turkish as a foreign language," we determined that teachers emphasized in both sub-themes that most Syrian students starting their first class at primary school were not speaking Turkish. Under those sub-themes, teachers also drew attention to the importance of arrangements aimed specifically at Syrian children, especially during the instruction of reading and writing.

Other studies conducted on this topic have reached similar conclusions, stating that a majority of Syrian students do not speak Turkish that they are just learning it, and that instructional arrangements have not been made on this subject (Taşkaya \& Ersoy, 2016; Dönmez \& Paksoy, 2015). Another important conclusion is that families migrating from Syria do not support their children with respect to their Turkish language skills, or with respect to their social lives, or within their familial environments. These conclusions propose that Syrian children who are trying to learn Turkish as a foreign language are facing difficulties just like many other foreigners. As a result, the readiness levels of those children would inevitably be lower than their peers during their learning of reading writing.

Classroom teachers stated that they have not received any education on the instruction of Turkish as a foreign language, but that this was a requirement with regard to their professional competency. In their study, Taşkaya \& Ersoy (2016) evaluated the practices used by classroom teachers in the instruction of Turkish to Syrian migrants. The findings of the study also propose that classroom teachers were not competent in instructing Turkish as a foreign language. On the other hand, Şahin (2014) emphasized that the instruction of Turkish as a foreign language should be made within the context of a special program, separate from other instructions. Under these circumstances, as we consider that Syrian children are attending general education schools in Turkey and that they are being taught reading and writing in Turkish as a foreign language, the education requirements of classroom teachers should not be disregarded. The fact that teachers are trying to teach Syrian children Turkish reading and writing skills without previously receiving any education on the instruction of Turkish as a foreign language during their undergraduate studies presents a challenge. The results of the study also support the results in the literature, revealing that teachers are not competent enough to instruct Turkish to Syrian children as a foreign language (Emin, 2016; Seydi, 2014).

In addition, teachers stated that the existing primary school program did not contain any arrangements on the instruction of Turkish reading and writing to foreigners. The results of the studies in the literature support this finding. Taşkaya \& Ersoy (2016) pointed out that there was no arrangement in the curriculum of primary schools regarding the instruction of reading and writing. Teachers indicated that professional competency was more important than professional seniority in the instruction of foreign languages. They therefore argued that giving in-service training to teachers on the instruction of Turkish as a foreign language was important. Teachers also indicated that appropriate materials should be prepared. This result is similar to the findings of the study conducted by Taşkaya \& Ersoy (2016), as well as the study conducted by Dönmez \& Paksoy (2015) in the literature.

Teachers stated that they preferred to use verbal and nonverbal communication for communicating with Syrian children. They highlighted the importance of gestures, mimics, games and visual materials in communication. It has been observed that they frequently evaluated students by using the in-class observation method and that they considered visual materials to be highly effective for establishing communication.

Teachers who also required physical arrangements that would facilitate the participation of migrant students in in-class activities stated that improvements should be made in matters such as the internet access of schools and classroom equipment such as televisions, computers and projectors. All teachers said they got most important support from their colleagues who are experienced in the instruction of Turkish as a foreign language and from students who speak Turkish as their native language. In this regard, Nurlu \& Kutlu (2015) state that academics have a duty in the instruction of Turkish to foreigners, and that there is no undergraduate program established for educating those academics. They also indicate that this deficiency was tried to be addressed with a postgraduate program provided at a very limited number of universities. Meanwhile, problems faced by teachers in terms of 
the lack of family participation in instructional arrangements and the individualization of in-class instruction are also considered to be important findings.

To conclude, we can argue that many problems are faced in the instruction of Turkish reading and writing skills to Syrian migrant children as a foreign language. These problems derive from a number of factors, such as the lack of public policies aimed at primary school programs concerning the instruction of Turkish as a foreign language, the fact that the number of trained instructors, support staff and specialists in the field is insufficient, uncertainties regarding the program to be implemented, and the fact that resources and materials are inadequate. Furthermore, there are also problems deriving from the structure of Turkish and the native languages of the children being taught (Ayaz \& Akkaya, 2010; Alyılmaz, 2010; Er, Biçer, \& Bozkırlı, 2012; Subaş1, 2010; Yıldırım, 2011; Yıldız \& Tunçel, 2012).

Teachers who establish direct communication with students newly started at primary school have important responsibilities in this respect. In this study, it has been observed that teachers experience problems related to the insufficiency of in-service training and professional development opportunities in different fields regarding the instruction of Turkish as a foreign language. According to the study, teachers also experience deficiencies in instruction materials, problems in effective inclusion skills, and difficulties concerning the supporting of students' adaptation skills, social skills and academic skills. In light of these findings, we may generally argue that teachers should receive education regarding the instruction of Turkish as a foreign language and should be given support regarding materials and the preparation of an inclusive environment in terms of adaptation and academic skills. One of the most important suggestions to be made in this respect is the preparation of instruction materials by the Ministry of National Education, as well as in-service training modules on the reading and writing program aimed at children from different cultures learning Turkish as a foreign language. Considering that Turkey is now a country that has allowed in a large number of migrants, a second suggestion is that classroom teachers should take courses during their undergraduate studies for instructing children not only in Turkish reading and writing but also in Turkish reading and writing as a foreign language.

Studies have been shown that, especially after 2011 there is significant increase population of Syrian immigrants and determined that permanent solutions need for supplying their basic needs (AFAD, 2014; Jennifer, 2015; Kilberg, 2014; UNHCR, 2015; UNICEF, 2015; ECHO, 2015). One of these basic needs is Syrian children have rights to involve education same as all children. All studies pointed out significance of education and it is necessary to solve the basic language barriers during this process (UNESCO, 2011). Although there are important scientific studies conducted in Turkey on the instruction of Turkish as a foreign language, how to instruct Turkish more easily and in a more systematic manner is a question that needs to be clarified. In this respect, it is expected that the findings obtained will help to guide the instruction of Turkish as a foreign language, the legal regulations to be made, and the new studies to be conducted.

\section{References}

AFAD (The Disaster and Emergency Management Presidency of Turkey). (2014). Population Influx from Syria to Turkey: Life in Turkey as a Syrian Guest. Ankara. Retrieved from www.afad.gov.tr/Dokuman/TR/148-20150202172457-11549547929971633783

Akış, İ. (2010). The main problems of related to the teaching of Turkish as a foreign language. New Studies in Teaching Turkish as a Foreign Language. 8. Symposium on Turkish Language Teaching in the Word. Ankara: Ankara University Printing Houses.

Akkaya, A. (2013). Syrian refugees' perception of the Turkish language. Journal of EKEV Academy, 56(56), 179-190.

Alyılmaz, C. (2010). Problems of Turkish teaching. Turkish Studies, 5(3), 728-749. https://doi.org/10.7827/TurkishStudies.1629

Ayaz, H \& Akkaya, A. (2010).Some thoughts on the problems encountered in teaching Turkish with foreigners. New studies in teaching Turkish as a foreign Language. 8. Symposium on Turkish Language Teaching in the World. Ankara: Ankara University Printing House.

Bogdan, C. R., \& Biklen, S. K. (2007). Qualitative reseach for education. Boston, MA: Allyn \& Bacon, Inc.

Creswell, J. (2005). Educational Research, planning, conducting and evaluating quantitative and qualtitative research. New Jersey: Pearson Merrill Prentice Hall. 
Dönmez, M. İ., \& Paksoy, S. (2015). A survey on the problems confronted by the Syrian students during their Turkish courses they take in Turkey: Kilis 7 December university sample. International Journal of Languages' Education and Teaching, UDES 2015, 1907-1919.

Elo, S., \& Kyngas, H. (2008). The qualitative content analysis process. Journal of Advanced Nursing, 62(1), 107-115. https://doi.org/10.1111/j.1365-2648.2007.04569.x

Emin, M. N. (2016). Education of Syrian children in Turkey: basic education policies-analysis. Ankara: SETA.

Er, O., Biçer, N., \& Bozkırll, K. Ç. (2012). Evaluation of problems encountered in Turkish teaching for foreigners in terms of related literatüre. International Journal of Turkish Literature Culture Education (TEKE), 1(2), 51-69. https://doi.org/10.7884/teke.51

European Commission Humanitarian Aid and Civil Protection (ECHO). (2014). Syria Crisis-Internal Displaced Persons and Syrian Refugees in the Region (as of December 11, 2014). Syria Crisis ECHO Fact Sheet. Retrieved from http://ec.europa.Eu/echo/files/aid/countries/factsheets/syria_en.pdf

İşcan, A. (2011). Importance of Turkish as foreign language. International Journal of Eurasia Social Sciences, 2(4), 29-36.

Kilberg, R. (2014). Turkey's evolving migration identity, Migration information source, Migration Policy Institute. Retrieved from http://www.migrationpolicy.org/article/turkeys-evolving-migration-identity

Kırkkılıç, A. (Ed.) (2002). Turkish lnguage written expression and composition information. Erzurum: Aktif Printing House.

MEB. (2014). Education services for foreigners. Retrieved from http://mevzuat.meb.gov.tr/html/yabyonegiogr_1/yabyonegiogr_1.html

Miles, M. B., \& Huberman. M. (1994). Qualittative data analysis: An expanded sourcebook (2th edition). Thousand Oaks, CA: Sage.

Nurlu, M., \& Kutlu, A. (2015). The issue of level spelling mistakes in teaching Turkish as a foreign language: The case of Afghanistan. Science Journal of Turkish Military Academy, 25(2), 67-87.

Patton, M. Q. (1987). Chapter 5 Depth interviewing. How to use qualitative methods in evaluation. Newbury Park, CA: Sage.

Roberts, J. (2015). Access to educational services by refugees in Turkey, Unpublished Presentation on 9th April, 2015 in UNHCR-NGO Coordination meeting.

Sahin, A. (Ed.) (2014). Teaching Turkish as a foreign language. Ankara: Pegem Publishing.

Seydi, A. R. (2014). The policies for the solution of educational problems of Syrian refugees in Turkey. Süleyman Demirel University Science and Literature Faculty Journal of Social Sciences, 31(1), 267-305.

Subaşı, A. D. (2010). Error analysis on composition of Arabian learners of Turkish at TÖMER. Journal of Language, 148, 7-16.

Taşkaya, S. M., \& Ersoy, G. (2016). The applications of primary school teachers in teaching Turkish to Syrian refugees. Journal of Cukurova Research, 2(1), 130-138.

Theirworld \& A World at School. (2015). Partnering for a better future: Ensuring Educational Opportunity for all Syrian Refugee Children and Youth in Turkey. Retrieved from http://www.aworldatschool.org/page/-/uploads/Reports/eirworld\%20

Tosun, C. (2006). Foreign language education problem. Journal of Language and Linguistic Studies, 2(1).

UNESCO (United Nations Educational, Scientific and Cultural Organization). (2011). The Hidden Crisis: Armed Conflict and Education, Efa Global Monitoring Report. Retrieved from http://unesdoc.unesco.org/images/0019/001907/190743e.pdf

UNHCR (United Nations High Commissioner for Refugees). (2015). Syria Regional Refugee Response Inter-agency Information Sharing Portal. Retrieved from http://data.unhcr.org/syrianrefugees/regional.php

UNICEF (United Nations International Children's Emergency Fund). (2015), Curriculum, acreditation, and certification for Syrian children in Syria, Turkey, Lebanon, Jordan, Iraq and Egypt. New York: UNICEF. Retrieved

from http://www.oosci-mena.org/uploads/1/wysiwyg/150527_CAC_for_Syrian_children_report_final.pdf

Yalçın, S. K., \& Şengül, M. (2007). The role and function of the language in the process of communication. 
Turkish Studies, 2, 249-769.

Yayl,, D., \& Bayyurt, Y. (Ed.) (2014). Teaching Turkish with Foreigners. Ankara: Pegem Publishing.

Yıldırım, A., \& Şimşek, H. (2011). Qualitative research methods in the social sciences (8th edition). Ankara: Seçkin Publishing.

Yıldırım, H. Ç., (2011). Student opinions regarding the Turkish grammar and nominal case suffixes in teaching Turkish as a foreign language. Gazi University, Ankara.

Yıldız, Ü., \& Tunçel, H. (2012). Problems and suggestions in teaching Turkish as a foreign language. Ankara: Pegem Academy.

\section{Appendix A}

\section{Teacher Interview Questions}

Q-1) According to you, what are the most important difficulties encountered in supporting the linguistic development and communication skills of children who are being educated in our country and whose foreign language is Turkish?

Q-2) What is the activity area that you most frequently refer to during the reading and writing processes of your migrant students whose foreign language is Turkish? Specify why do you prefer those activities.

Q-3) What are your opinions regarding your communication with the families of students during the reading comprehension and writing processes of children for whom Turkish is a foreign language? How do you contact them and what kind of attitude do the families adopt?

Q-4) What is your priorty for determining level of teaching practices and talk permit of students for inclusion after Syrian students with turkish as a second language attend the class? (questions or observation, which one do you prefer)

Q-5) What is your most effective strategy and method to teaching reading-writing and understanding practices (think of pre and post-proceed) for immigrant students? Could you provide any benefical sources during this process?

Q-6) What are your opinions regarding the effects of preparation for reading, writing, linguistic development, peer interaction and class participation on children for whom Turkish is a foreign language? What kind of arrangements do you make to ensure the children's adaptation to the process?

Q-7) What are the instructional materials you consider to be most efficient during the reading comprehension and writing processes of your migrant students? (Answer by considering materials such as films, games, videos, books, etc.). What are your opinions regarding the reading and writing activities in the curriculum?

Q-8) Have you faced any negativity with regard to activities, planning or classroom management after migrant children for whom Turkish is a foreign language started attending your classes? What kind of arrangements have you made in such cases?

Q-9) Have you ever obtain any feedback from parents (Syriand and Turkish)about reading-writting and understanding practises in class? (about children's school and home activities)

Q-10) What kind of support should be given to teachers instructing migrant for whom Turkish is a foreign language? What are your suggestions on this topic?

\section{Copyrights}

Copyright for this article is retained by the author(s), with first publication rights granted to the journal.

This is an open-access article distributed under the terms and conditions of the Creative Commons Attribution license (http://creativecommons.org/licenses/by/4.0/). 